\title{
Peningkatan Keterampilan ICT untuk Guru melalui Pelatihan Konten Digital Pembelajaran Berbasis Sumber Terbuka (Open Sources)
}

\author{
Taufik Ikhsan Slamet ${ }^{1}$, Agung Alfiansyah ${ }^{2}$, Wikky F. Al Maki ${ }^{3}$, Fathoni A. \\ Musyafa $^{4}$, Alfa Satyaputra ${ }^{5}$, Patmah Fathoni ${ }^{6}$, Shinta S. Andayani ${ }^{7}$, Sherly \\ Melinda $^{8}$, Dominggus Oktavianus ${ }^{9}$, Nuiza P. Yusuf ${ }^{10}$ \\ ${ }^{1}$ Teknologi Pendidikan, Fakultas Ilmu Pendidikan, Universitas Negeri Malang \\ 2,3,4,5,6,7,8,9,10 Pendidikan Teknik Informatika dan Komputer, Surya College of \\ Education \\ Email: taufik.ikhsan.tep@um.a.cid ${ }^{1}$ \\ *Corresponding author: Taufik Ikhsan Slamet
}

\begin{abstract}
ABSTRAK
Pemanfaatan dan pengembangan konten digital adalah persyaratan yang harus terpenuhi untuk menjadi guru profesional Abad 21. Hal ini yang kemudian membuat adanya kebutuhan mendesak dikalangan guru yang sudah lama berkecimpung dalam profesi pendidikan. Berdasarkan survey yang dilakukan melalui kuesioner online (Google Form), responden ( $n=83)$ dari beberapa sekolah dan beberapa mata pelajaran mengayatakan bahwa kebutuhan keterampilan pembuatan konten digital pembelajaran merupakan prioritas utama $(n=42)$ dan diikuti kebutuhan pembuatan online classroom and mobile learning $(\mathrm{n}=38)$. Artikel ini bertujuan untuk menyampaikan identifikasi masalah, analisa kurikulum, implementasi solusi, dan evaluasi hasi dari kegiatan pengabdian pada masyarakat dalam bentuk pelatihan pengembangan konten digital pembelajaran untuk guru di Kota Tangerang.
\end{abstract}

Kata Kunci: konten digital; pembelajaran informatika; sumber terbuka.

\section{ABSTRACT}

Digital content development and utilization are considered as high requirements that must be mastered by qualified teachers in this $21^{\text {st }}$ century learning. The needs eventually create gaps between prior teachers' competencies and the requirements for further qualifications. An online survey delivered through Google form was conducted to validate this hypothesis. The survey found that respondents $(n=83)$ who were school teachers from different learning subjects expressed that they demanded new skills on digital content development and utilization. It was considered as the highest priority $(n=42)$ among any others skills related technology enhanced learning, such as online classroom or mobile learning $(n=38)$. This article is aimed to describe the process of problem identification, curriculum analysis, the implementation of solution, and program evaluation of a community service activities entitled 'Training of Digital Content Development for School Teachers'

Keywords: computer science education; digital content; open sources.

\section{PENDAHULUAN}

Penggunaan konten digital dalam belajar dan pembelajaran mengalami peningkatan secara kuantitas dan kualitas. Sebagai contoh, terjadi perubahan paradigma belajar bahwa siswa harus mampu membuat konten digital yang bermanfaat untuk 
disebarkan ("Preparing Students To Produce Digital Content," 2015). Keterampilan ini memilki fungsi yang bergandar dari sisi pembelajaran. Pertama, siswa akan mengulangi konten pelajaran ketika membuat media. Dan kedua, mereka akan berlatih menyampaikan informasi secara efektif dan efisien.

Berdasarkan pemerolehan nilai PISA (Programme for International Student Assessment) pada Tahun 2015 yang dilakukan oleh Organisation for Economic Co-operation and Development (OECD, 2015), Indonesia menempati peringkat 63 dari 72 negara dunia yang terlibat dalam survey. PISA menjadi indikator gambaran tentang kualitas outcome pembelajaran yang dilaksanakan selama ini, dan peringkat tersebut menggambarkan bahwa kualitas pembelajaran dan hasil yang dicapai sangat belum memuaskan dan mencapai hasil yang optimal. Beberapa upaya dilakukan pemerintah untuk kemudian menghasilkan outcome pendidikan yang lebih memiliki kualitas, salah satunya adalah dengan peningkatan performa guru dalam melaksanakan kegiatan pembelajaran. Upaya ini dilakukan dalam bentuk pelatihan, workshop, penelitian, hingga peningkatan salary (gaji) yang didapatkan guru. Namun, untuk upaya terakhir, ternyata tidak memberikan manfaat yang signifikan. Pemberian salary rate yang tinggi ternyata hanya memberikan dampak positif pada kepuasan guru terhadap income, mengurangi peluang guru memiliki kerja sampingan, dan mengurangi komplain terhadap income yang kecil (De Ree, Muralidharan, Pradhan, \& Rogers, 2015).

Salah satu komponen penting yang harus dimiliki guru dalam melaksanakan pembelajaran Abad 21 adalah kemampuan menggunakan hingga membuat sumber belajar berbasis ICT (TIK) untuk keperluan pembelajaran. ICT (Information Communication Technology) secara umum didefinisikan sebagai teknologi yang digunakan untuk mendapatkan, mengumpulkan, merekayasam dan menampilkan atau mengkomunikasikan informasi. Teknologi tersebut dapat berukan perangkat keras seperti komputer atau alat lainnya, perangkat lunak aplikasi, dan konektivitas seperti internet, jaringan loka, dan video konferensi (Anderson \& Glenn, 2003). Berdasarkan konsep tersebut, peran guru dalam mengadaptasi ICT dalam pembelajaran adalah pada konteks pembuatan dan penyajian informasi belajar kepada para peserta didik. Sehingga, guru minimal dapat menggunakan atau bahkan membuat material belajar dalam format yang mendukung penerapan ICT.

Sebagai prediksi akan kondisi kemampuan ICT para tenaga pendidik di Indonesia, data yang didapat dari penelitian (Yusuf, 2016) tentang implementasi ICT pada pendidikan guru sekolah dasar di Indonesia cukup mewakilkan kondisi tersebut.

Tabel 1. Kapabilitas peserta pendidikan keguruan sekolah dasar dalam menggunakan perangkat lunak ICT (Yusuf, 2016)

\begin{tabular}{llll}
\hline No. & Office Application & Capable (\%) & Not Capable (\%) \\
\hline 1 & Word processing & $43,8 \%$ & $56,2 \%$ \\
2 & Spreadsheet & $71,0 \%$ & $29,0 \%$ \\
3 & Powerpoint & $58,8 \%$ & $41,2 \%$ \\
\hline
\end{tabular}


Taufik Ikhsan Slamet ${ }^{1}$, Agung Alfiansyah ${ }^{2}$, Wikky F. Al Maki ${ }^{3}$, Fathoni A. Musyafa ${ }^{4}$, Alfa Satyaputra ${ }^{5}$, Patmah Fathoni ${ }^{6}$, Shinta S. Andayani ${ }^{7}$, Sherly

Melinda ${ }^{8}$, Dominggus Oktavianus ${ }^{9}$, Nuiza P. Yusuf ${ }^{10} /$ Aksiologiya: Jurnal Pengabdian Kepada Masyarakat. Vol.4, No.1, Februari 2020 Hal 118-130

\begin{tabular}{llll}
\hline No. & Office Application & Capable (\%) & Not Capable (\%) \\
\hline 4 & E-mail & $58,8 \%$ & $42,0 \%$ \\
5 & Internet & $29,3 \%$ & $70,7 \%$ \\
6 & Statistic tools & $37,9 \%$ & $62,71 \%$ \\
\hline
\end{tabular}

Tabel 2. Penggunaan ICT dalam aktivitas pembelajaran (Yusuf, 2016)

\begin{tabular}{llll}
\hline No. & \multicolumn{1}{c}{ Activities } & $\begin{array}{c}\text { \% of using } \\
\text { ICT }\end{array}$ & $\begin{array}{c}\text { \% of not } \\
\text { using ICT }\end{array}$ \\
\hline 1 & Teaching-learning specific object & $20 \%$ & $80,0 \%$ \\
2 & $\begin{array}{l}\text { Finding and accessing information and } \\
\text { educational materials }\end{array}$ & $31,4 \%$ & $68,6 \%$ \\
3 & Making presentations and lecture & $40,3 \%$ & $59,7 \%$ \\
4 & Preparing lessons & $27,9 \%$ & $72,1 \%$ \\
5 & Communicating with students & $24,3 \%$ & $75,7 \%$ \\
6 & Preparing reports & $25,8 \%$ & $74,2 \%$ \\
\hline
\end{tabular}

Berdasarkan data di Tabel 1 dan 2, dapat dilihat bahwa kemampuan ICT para guru baru pada tahap dasar dari operasi pembuatan dokumen. Hal ini diprediksi karena perangkatperangkat lunak tersebut paling banyak digunakan untuk keperluan dokumentasi dan pelaporan pebelajaran dan administrasi. Data tersebut membuktikan bahwa ICT belum secara optimal dilibatkan dalam kegiatan belajar dan mengajar. Untuk optimalisasi, ICT harus diintegrasikan secara menyeluruh dalam proses pedagogi, dan melibatkan banyak pihak seperti pengambil kebijakan, pengembang kurikulum, dan manajemen (Tatang, 2007).

Pelatihan pembuatan konten digital untuk para guru dilintas tingkat pendidikan ini pada akhirnya bertujuan tidak hanya agar guru memiliki keterampilan dalam menggunakan dan membuat konten digital secara mandiri. Namun, jangka panjangnya konten digital ini dapat pula disebarluaskan untuk kemudian digunakan secara masal dan terbuka. Pelatihan ini disebarluaskan secara terbuka di internet, sehingga dimanapun guru yang ingin berpartisipasi, dapat berperan serta.

\section{METODE}

\section{Tahapan dan Metode Pelaksanaan Kegiatan}

Pengabdian kepada masyarakat dilaksanakan berdasarkan prosedur model pengembangan instruksional bernama ADDIE (Analysis, Design, Development, Implementation, and Evaluation) (Bichelmeyer, 2005; Davis, 2013; Molenda, 2003). ADDIE merupakan model yang prosedural dan sistemik (Gustafson \& Branch, 2002), sehingga setiap tahapan saling berhubungan dan harus dilakukan sesuai dengan teori.

\section{Tahapan Analisis (Analysis Phase)}

Pada tahap analisis, penulis dan tim melakukan sebuah survey dalam jaringan (online) untuk melihat apa yang dibutuhkan para guru dalam mengimplementasikan ICT dalam pembelajaran. Studi dilakukan melalui metode survey dengan memanfaatkan fitur Google Form, yang kemudian disebar dibanyak platform media sosial (Facebook dan Twitter) dan fitur 
Taufik Ikhsan Slamet', Agung Alfiansyah ${ }^{2}$, Wikky F. Al Maki ${ }^{3}$, Fathoni A. Musyafa ${ }^{4}$, Alfa Satyaputra ${ }^{5}$, Patmah Fathoni ${ }^{6}$, Shinta S. Andayani ${ }^{7}$, Sherly Melinda ${ }^{8}$, Dominggus Oktavianus ${ }^{9}$, Nuiza P. Yusuf ${ }^{10}$ / Aksiologiya: Jurnal Pengabdian Kepada Masyarakat. Vol.4, No.1, Februari 2020 Hal 118-130

mailing list pada Google kepada database yang sudah ada pada institusi.

Beberapa item pertanyaan yang diberikan dalam online survey tersebut adalah a) demografi responden, b) sumber belajar yang umumnya digunakan dalam pembelajaran, dan c) kompetensi pendukung terkait ICT yang dibutuhkan untuk mendukung pembelajaran. Demografi responden meliputi profil umum dari responden
(Gambar 1), seperti variabel usia, lama karir mengajar, mata pelajaran yang diampu, tempat mengajar, gender, dan tingkat kelas yang diajar. Selanjutnya, indikator sumber belajar berkenaan dengan jenis sumber belajar yang digunakan ketika pembelajaran dilaksanakan, seperti buku teks atau LKS (Gambar 2). Hasil survey tersebut dapat ditampilkan pada bagan-bagan berikut.

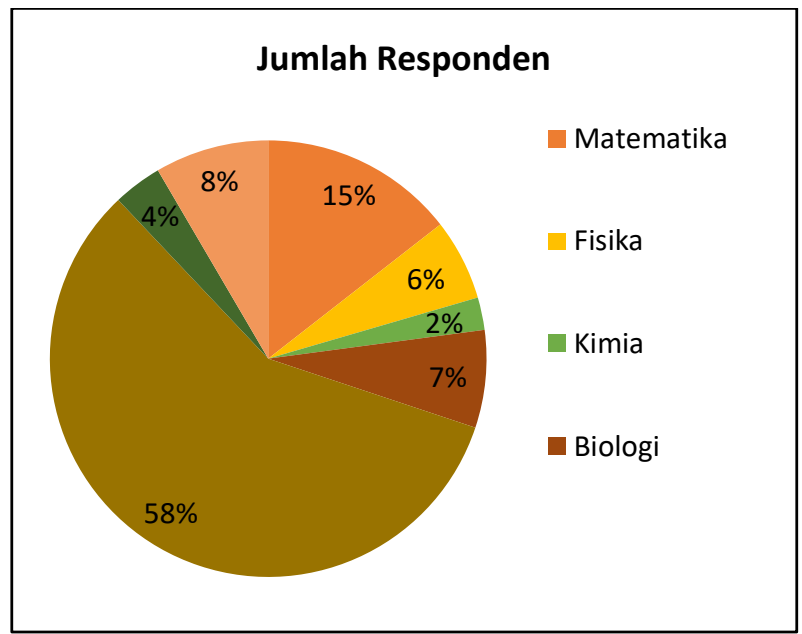

Gambar 1. Sebaran responden pada survey

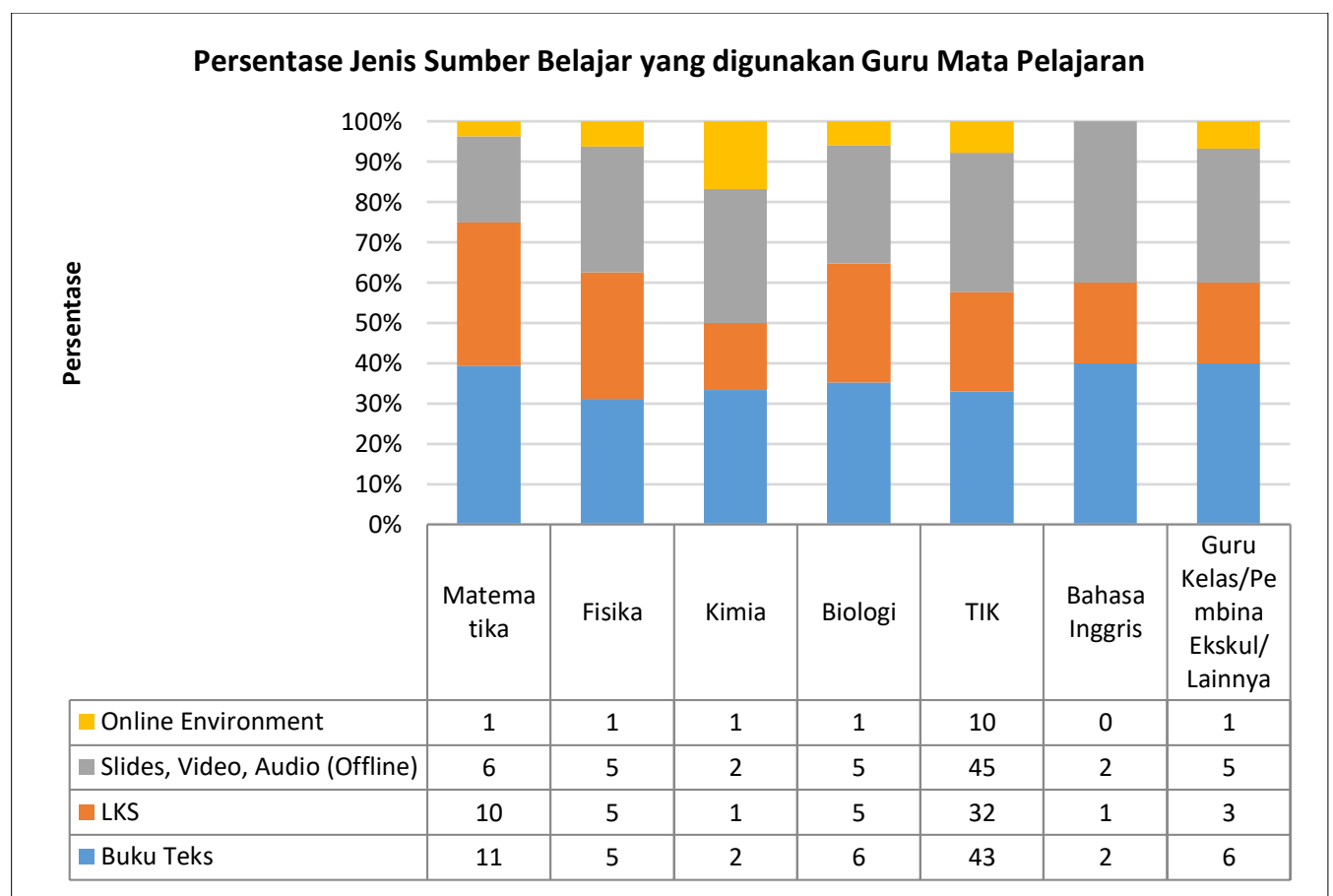

Gambar 2. Persentase penggunaan jenis sumber belajar oleh responden 
Ganbar 1 dan 2 merupakan hasil survey yang dilakukan pada sebanyak 78 responden, dengan sebaran mata pelajaran dari yang terbanyak: a) TIK (n: 43), b) Matematika (n: 12), c) Guru Kelas (n: 7), d) Biologi (n: 6), e) Fisika (n: 5), f) Bahasa Inggris (n: 3), dan g) Kimia (n: 2). Bagan selanjutnya mendeskripsikan jenis sumber belajar yang dominan digunakan oleh tiap guru masing-masing mata pelajaran dari empat jenis sumber yang familiar digunakan dalam pembelajaran. Variabilitas data sekilas memiliki rentang yang cukup sempit, diakibatkan dominasi salah satu indikator dalam responden (TIK). Selanjutnya, dalam survey tersebut dicari pula data yang berkenaan dengan kebutuhan guru dalam penggunaan dan pembuatan sumber belajar berbasis digital, dengan kriteria pilihan a) online and mobile learning, b) digital content, c) information presentation, d) office suite, e) class management, dan f) operating system.

Jenis dalam pilihan material tersebut didasarkan pada jenis material digital yang secara umum digunakan dan berpotensi kuat dalam membantu peserta didik belajar secara efektif dan efisien.

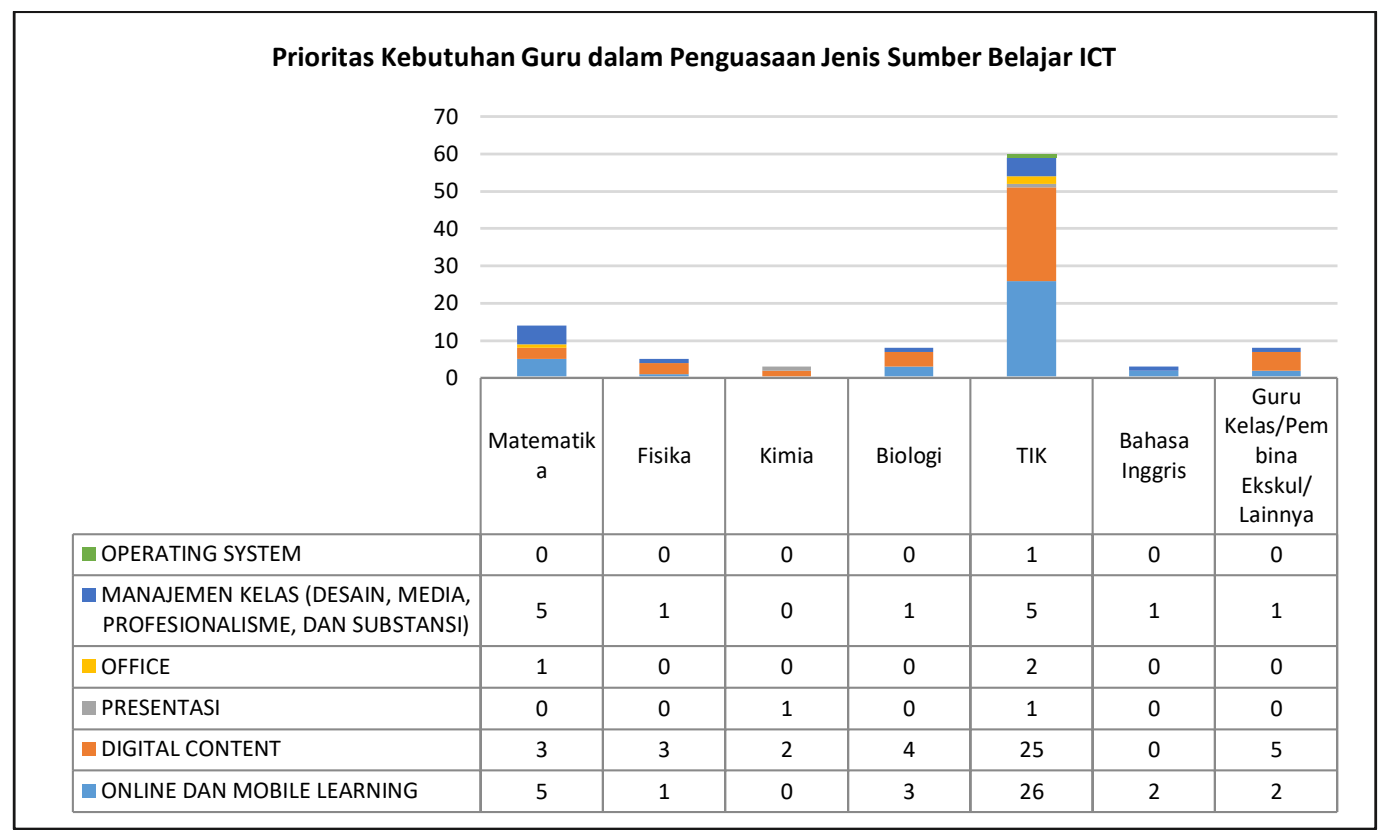

Gambar 3. Prioritas keterampilan yang dibutuhkan berdasarkan persepsi responden

Berdasarkan hasil survey yang ditampilkan pada Gambar 3, kebutuhan digital content secara signifikan jauh lebih dibutuhkan dari bentuk material lainnya. Hal ini menandakan bahwa responden memahami tuntutan dan standar yang akan diberlakukan dalam pembelajaran untuk setiap guru memanfaatkan ICT untuk pembelajaran. Informasi positif lainnya adalah bahwa guru sudah sadar bahwa kebutuhan konten digital dalam pembelajaran saat ini menjadi trend yang harus dipenuhi dan tersedia dalam proses pembelajaran. 
Taufik Ikhsan Slamet', Agung Alfiansyah ${ }^{2}$, Wikky F. Al Maki ${ }^{3}$, Fathoni A. Musyafa ${ }^{4}$, Alfa Satyaputra ${ }^{5}$, Patmah Fathoni ${ }^{6}$, Shinta S. Andayani ${ }^{7}$, Sherly

Melinda $^{8}$, Dominggus Oktavianus ${ }^{9}$, Nuiza P. Yusuf ${ }^{10}$ / Aksiologiya: Jurnal Pengabdian Kepada Masyarakat. Vol.4, No.1, Februari 2020 Hal 118-130

\section{Tahapan Perencanaan (Design Phase)}

Kegiatan utama pada tahap perencanaan adalah kegiatan pengembangan kurikulum pelatihan. Pada tahap ini, ditentukan tujuan umum dan khusus pelatihan, beserta komponen penting dari sebuah kurikulum, seperti rumpun mata latih, mata latih, dan tujuan mata latih. Setelah menyelesaikan kurikulum, selanjutnya yang disusun adalah silabus mata latih yang nantinya akan dilaksanakan dalam pembelajaran. Kurikulum dan silabus pelatihan kemudian disusun dalam sebuah dokumen bernaman training manual. Training manual merupakan pedoman yang diberikan kepada peserta pelatihan nantinya sebagai petunjuk dan prosedur program pelatihan.

\section{Tahapan (Development Phase) \\ Pengembangan}

Dalam kegiatan pelatihan ini, tahap pengembangan merupakan perwujudan dari hasil pada tahap perencanaan (design phase) menjadi bentuk materi pelatihan dan sumber belajar yang terkait. Silabus pelatihan sebagai bagian spesifik dari sebuah kurikulum pelatihan kemudian dijadikan pedoman untuk memproduksi materi pelatihan dalam bentuk teks dan multimedia. Kegiatan pengembangan dilakukan oleh masing-masing individu yang bertanggungjawab terhadap mata latih tertentu. Didalam materi biasanya terdapat muatan kurikulum dan pedoman praktikum yang nanti dilakukan ketika pelaksanaan.

\section{Tahapan (Implementation Phase) \\ Pelaksanaan}

Tahap pelaksanaan merupakan kegiatan inti yang melibatkan pelaksana dan peserta pelatihan. Dalam kegiatan pengabdian ini, target peserta pelatihan adalah para guru ditingkat SD, SMP, ataupun SMA sederajat. Pelaksanaan pelatihan dilaksanakan berdasarkan prinsip pembelajaran tutorial (observational learning) dari teori belajar social learning milik Albert Bandura (Bandura \& Walters, 1963). Observational learning sendiri memiliki empat tahapan belajar yang dianggap paling sesuai dengan pelaksanaan pelatihan bidang keterampilan, yang meliputi fase a) atensi, b) retensi, c) reproduksi, dan d) motivasi (Yi \& Davis, 2003).

\section{HASIL}

\section{Muatan Kurikulum Pelatihan}

Kurikulum

yang

dikembangkan secara teoritis dilakukan melalui pengembangan kurikulum strategis (bottom up), artinya kurikulum dikembangkan berdasarkan kebutuhan nyata sasaran dan jauh dari pengaruh politis pemangku jabatan (Fullan, 1994). Berdasarkan hasil analisa kebutuhan, maka disusun kurikulum yang menjadi panduan setiap pelatih dalam menyelenggarakan pembelajaran.

Tujuan pelatihan: membiasakan guru untuk membiasakan diri menghasilkan material pembelajaran yang adaptif terhadap IPTEK melalui pemanfaatan sumber terbuka (open sources).

Kompetensi umum: guru mampu membuat beberapa jenis multimedia yang memiliki muatan pembelajaran 
Kompetensi khusus:

1. Guru dapat menganalisis kebutuhan media berdasarkan teknik analisis kebutuhan

2. Guru dapat menggunakan perangkat lunak pengolah grafis untuk membuat media pembelajaran bentuk grafis

3. Guru dapat menggunakan perangkat lunak pengolah audiountuk membuat media pembelajaran bentuk podcast

4. Guru dapat menggunakan perangkat lunak pengolah audiovisual untuk membuat media pembelajaran bentuk video sesuai standar MOOCs

5. Guru dapat menggunakan perangkat lunak pengolah electronic quiz untuk membuat media pembelajaran bentuk online quiz

6. Guru dapat menggunakan perangkat lunak pengolah animasi untuk membuat media pembelajaran bentuk animasi bergerak

7. Guru dapat menggunakan perangkat lunak pemrograman dasar untuk membuat media pembelajaran simulasi ilmiah

Tabel 3. Muatan kurikulum pelatihan

\begin{tabular}{clcll}
\hline $\begin{array}{c}\text { Kompetensi } \\
\text { Khusus }\end{array}$ & \multicolumn{1}{c}{ Mata Pelatihan } & $\begin{array}{c}\text { Jam } \\
\text { Pelatihan }\end{array}$ & $\begin{array}{c}\text { Perangkat } \\
\text { lunak }\end{array}$ & \multicolumn{1}{c}{ Instruktur } \\
\hline 1 & $\begin{array}{l}\text { Konten Digital dan } \\
\text { Perencanaan Media }\end{array}$ & 2 & $\begin{array}{l}\text { Front-end } \\
\text { analysis }\end{array}$ & Taufik Ikhsan S. \\
\hline 2 & $\begin{array}{l}\text { Desain Grafis Media } 2 \\
\text { Dimensi }\end{array}$ & 3 & $\begin{array}{l}\text { Gimp dan } \\
\text { Inkscape }\end{array}$ & $\begin{array}{l}\text { Alfa Satyaputra } \\
\text { Dominggus O. }\end{array}$ \\
\hline 3 & $\begin{array}{l}\text { Media Audio dan } \\
\text { Podcast }\end{array}$ & 3 & Audacity & $\begin{array}{l}\text { Wikky F. Al } \\
\text { Maki }\end{array}$ \\
\hline 4 & $\begin{array}{l}\text { Audio-Video untuk } \\
\text { MOOCs }\end{array}$ & 2 & Lightwave & $\begin{array}{l}\text { Fathoni A. } \\
\text { Musyafa }\end{array}$ \\
\hline 5 & Electronic Quiz & 2 & $\begin{array}{l}\text { Quiz } \\
\text { Creator }\end{array}$ & Siti Sinta A. \\
\hline 6 & Animasi Pembelajaran & 2 & Synfig & $\begin{array}{l}\text { Patmah Fatoni } \\
\text { Sherly Melinda }\end{array}$ \\
\hline 7 & Pemrograman Dasar & 2 & Processing & $\begin{array}{l}\text { Agung } \\
\text { Alfiansyah }\end{array}$ \\
\hline
\end{tabular}

Muatan kurikulum pada Tabel 3 di atas diselenggarakan dalam dua hari pelatihan, dengan masing-masing hari berisi delapan jam pelatihan (1 jam $=50$ menit). Seluruh materi pelatihan disatukan kedalam emodule yang diberikan pada peserta ketika pelaksanaan pelatihan. Emodule tersebut juga dilengkapi dengan bahan pelatihan pendukung lainnya, seperti material multimedia dan perangkat lunak open source yang digunakan.
Pelatihan ini selain bertujuan untuk membantu para guru dalam melatih keterampilan penggunaan perangkat ICT untuk pembeajaran, juga diarahkan pada pengenalan dan sosialisasi mengenai Hak Kekayaan Intelektual. Tujuan tersebut diwujudkan melalui penggunaan perangkat lunak yang berbasis sumber terbuka (open source). Oleh karena itu, seluruh perangkat lunak dan tutorial yang digunakan dalam pelatihan ini cukup tidak familiar 
dikalangan guru atau responden. Hal ini dilakukan agar guru nantinya juga ikut serta dalam mempublikasikan perangkat lunak open source kepada para siswa, sehingga pembelajaran yang dilakukan tidak terkendala biaya yang sering dituntut ketika menggunakan produk perangkat lunak yang berbayar.

\section{Sosialisasi Program Pelatihan}

Kegiatan pengabdian pada masyarakat dalam bentuk pelatihan ini terbuka untuk guru dan tenaga pendidik dimanapun. Pelaksana sengajar tidak membatasi untuk cakupan institusi atau lembaga tersebut untuk mendapatkan variabilitas peserta dan dampak yang lebih luas. Dengan tujuan tersebut, sosialisasi program pelatihan dilakukan gencar secara online melalui jejaring sosial dan media sosial. Platform seperti Facebook dan Twitter menjadi sarana utama dalam diseminasi informasi pelatihan, ditambah dengan metode konvensional seperti pengiriman

Tabel 4. Daftar sebaran peserta pelatihan

\begin{tabular}{llll}
\hline \multicolumn{1}{c}{ Nama Lembaga } & \multicolumn{1}{c}{ Asal } & $\begin{array}{l}\text { Jumlah } \\
\text { Peserta }\end{array}$ & \multicolumn{1}{c}{ Bidang Studi } \\
\hline SMK Islamic Village & $\begin{array}{l}\text { Kota Tangerang } \\
\text { Selatan }\end{array}$ & 2 peserta & $\begin{array}{l}\text { TIK (Teknologi Informasi } \\
\text { dan Komunikasi) }\end{array}$ \\
\hline SDI Al Azhar BSD & $\begin{array}{l}\text { Kota Tangerang } \\
\text { Selatan }\end{array}$ & 1 peserta & $\begin{array}{l}\text { TIK (Teknologi Informasi } \\
\text { dan Komunikasi) }\end{array}$ \\
\hline SMAN 8 Tangerang & $\begin{array}{l}\text { Kota Tangerang } \\
\text { Selatan }\end{array}$ & 1 peserta & $\begin{array}{l}\text { TIK (Teknologi Informasi } \\
\text { dan Komunikasi) }\end{array}$ \\
\hline LPKI Depok & Kota Depok & 1 peserta & $\begin{array}{l}\text { TIK (Teknologi Informasi } \\
\text { dan Komunikasi) }\end{array}$ \\
\hline SMKN 1 Kragilan & Banten & 2 peserta & $\begin{array}{l}\text { TIK (Teknologi Informasi } \\
\text { dan Komunikasi); } \\
\text { Bahasa Indonesia }\end{array}$ \\
\hline SMK Yapia Parung & Kota Depok & 1 peserta & Akuntansi \\
\hline $\begin{array}{l}\text { SMA Santa Ursula } \\
\text { BSD }\end{array}$ & $\begin{array}{l}\text { Kota Tangerang } \\
\text { Selatan }\end{array}$ & 3 peserta & $\begin{array}{l}\text { Geografi; } \\
\text { Kimia; } \\
\text { Biologi }\end{array}$ \\
\hline $\begin{array}{l}\text { Univ. Kristen Duta } \\
\text { Wacana }\end{array}$ & DIY & 1 peserta & Ilmu Komputer \\
\hline
\end{tabular}

surat undangan pelatihan untuk sekolah-sekolah satu kota dan pernah menjadi mitra dengan institusi pelaksana.

Rekrutmen peserta dilakukan kurang lebih satu setengah bulan sebelum pelaksanaan pelatihan. Proses resgistrasi dilakukan secara daring melalui tautan yang berikan pada undangan online dan cetak. Formulir pendaftaran disisipkan pada website resmi yang sengajar dibuat untuk keperluan pengabdian ini, dengan alamat http://icttraining.stkipsurya.ac.id. Dalam masa rekrutmen diperoleh respon yang cukup memuaskan dari para netizen, yang kebanyakan dari responden adalah guru, tenaga administrasi, teknisi sekolah, dan dosen. Setelah melakukan penyaringan dan konfirmasi, peserta pelatihan yang memastikan kehadiran dalam pelatihan tersebut berjumlah 24 peserta, dengan sebaran sebagai berikut. 
Taufik Ikhsan Slamet ${ }^{1}$, Agung Alfiansyah ${ }^{2}$, Wikky F. Al Maki ${ }^{3}$, Fathoni A. Musyafa ${ }^{4}$, Alfa Satyaputra ${ }^{5}$, Patmah Fathoni ${ }^{6}$, Shinta S. Andayani ${ }^{7}$, Sherly Melinda ${ }^{8}$, Dominggus Oktavianus ${ }^{9}$, Nuiza P. Yusuf ${ }^{10}$ / Aksiologiya: Jurnal Pengabdian Kepada Masyarakat. Vol.4, No.1, Februari 2020 Hal 118-130

\begin{tabular}{llll}
\hline \multicolumn{1}{c}{ Nama Lembaga } & \multicolumn{1}{c}{ Asal } & $\begin{array}{l}\text { Jumlah } \\
\text { Peserta }\end{array}$ & \multicolumn{1}{c}{ Bidang Studi } \\
\hline SMKN 7 Tangerang & $\begin{array}{l}\text { Kota Tangerang } \\
\text { Selatan }\end{array}$ & 2 peserta & $\begin{array}{l}\text { Matematika; } \\
\text { Produktif Akuntansi }\end{array}$ \\
\hline SDS Islamic Village & Kota Tangerang & 1 peserta & NA \\
\hline SMAN 1 Kibin & Banten & 2 peserta & Fisika \\
\hline SMA Islamic Village & $\begin{array}{l}\text { Kota Tangerang } \\
\text { Selatan }\end{array}$ & 2 peserta & NA \\
\hline SMAN 8 Tangsel & $\begin{array}{l}\text { Kota Tangerang } \\
\text { Selatan }\end{array}$ & 2 peserta & $\begin{array}{l}\text { Biologi; } \\
\text { Matematika }\end{array}$ \\
\hline SMKN 5 Tangerang & $\begin{array}{l}\text { Kota Tangerang } \\
\text { Selatan }\end{array}$ & 2 peserta & NA \\
\hline
\end{tabular}

NA: Not available

\section{Pelaksanaan Pelatihan}

Pelatihan dilaksanakan pada tanggal 2 dan 3 Februari 2015 dan bertempat di Laboratorium Komputer, Gedung Surya Research and Education (SURE), Surya College of Education. Jadwal pelatihan dilaksanakan secara prosedural sesuai kurikulum pelatihan, dimulai dari mata latih 1) Konten Digital dan Perencanaan Media, 2) Desain Grafis Media 2 Dimensi, 3) Media Audio dan Podcast, 4) Audio-Video untuk MOOCs. Keempat mata latih tersebut diberikan dihari pertama pelatihan, sedangkan mata latih 5) Electronic Quiz, 6) Animasi Pembelajaran, dan 7) Pemrograman Dasar, diberikan dihari kedua pelatihan. Seluruh material pelatihan disimpan dalam drive pada setiap PC yang ada di laboratorium, sehingga setiap peserta secara bebas dapat menyimpan semua material secara bebas.

Mata pelatihan pertama dalam pelatihan ini adalah pengenalan bentuk konten digital yang dapat dimanfaatkan dalam pembelajaran beserta sebuah teknik untuk mengukur kebutuhan media yang harus dikembangkan. Materi ini menjadi penting karena pengembangan konten digital (multimedia) harus memiliki dasar yang faktual untuk menentukan fitur yang harus tersedia dalam media. Kebanyakan guru atau pengembang media rerata tidak melakukan hal ini, karena dianggap kebutuhan tersebut sesuai dengan persepsi si pengembang. Padahal, tahapan ini sangat penting untuk dilakukan, mengingat efektivitas dan efisiensi dalam pengembangan dan implementasi media adalah hal yang utama.

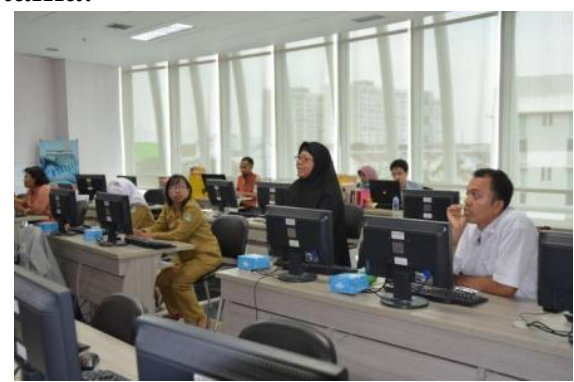

Gambar 4. Peserta pelatihan pengembangan konten digital edukatif

Pada materi ini, peserta mempelajari teknik Front-End Analysis, yang banyak digunakan dalam proses analisa sistem. Instruktur mendemonstrasikan teknik ini dalam simulasi sederhana dalam pengembangan multimedia pembelajaran, sehingga dengan mudah dapat digunakan para guru 
Taufik Ikhsan Slamet ${ }^{1}$, Agung Alfiansyah ${ }^{2}$, Wikky F. Al Maki ${ }^{3}$, Fathoni A. Musyafa ${ }^{4}$, Alfa Satyaputra ${ }^{5}$, Patmah Fathoni ${ }^{6}$, Shinta S. Andayani ${ }^{7}$, Sherly Melinda $^{8}$, Dominggus Oktavianus ${ }^{9}$, Nuiza P. Yusuf ${ }^{10}$ / Aksiologiya: Jurnal Pengabdian Kepada Masyarakat. Vol.4, No.1, Februari 2020 Hal 118-130

nantinya untuk keperluan pengembangan media.

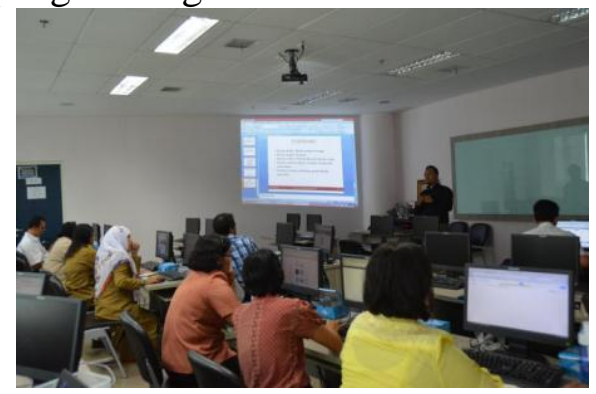

Gambar 5. Penyampaian materi

konten digital dalam pembelajaran

Mata pelatihan kedua adalah pembuatan konten media 2 dimensi dengan menggunakan perangkat lunak GIMP dan Inkscape. Kedua perangkat ini bersifat open source, sehingga peserta ataupun pengguna lainnya tidak perlu khawatir akan lisensi dan fitur premium yang sering ada dalam perangkat lunak berbayar.

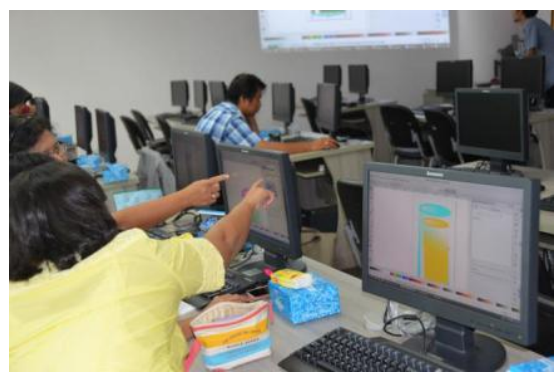

Gambar 6. Peserta mempraktekkan penggunaan GIMP dan Inkscape untuk media 2 dimensi

Seperti tahapan observational learning, instruktur setiap sesi pelatihan memberikan sebuah simulasi dan tutorial untuk produk yang mudah terlebih dulu. Peserta mengikuti secara bertahap mengikuti sembari dibantu oleh asisten insruktur yang berasal dari kalangan mahasiswa Prodi TIK Surya College of Education.

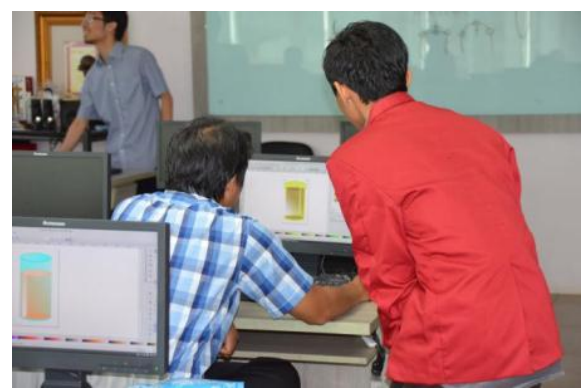

Gambar 7. Pendampingan oleh asisten instruktur pada peserta

Mata pelatihan ketiga dan keempat, yaitu konten audio (podcast) dan video pembelajaran disampaikan dengan teknik yang sama. Perangkat lunak yang digunakan dalam mata latih ini adalah perangkat open source bernama Audacity dan Lightwave. Kedua perangkat lunak ini tidak berbayar dan dapat diunduh secara gratis, namun untuk Lightwave penggunaan akan optimal jika penggunaan tersambung dengan koneksi internet. Pada mata pelatihan ini, peserta menggunakan headset untuk mengoptimalkan penggunaan kedua perangkat lunak. Konten audio dan video pembelajaran dari sisi penggunaan adalah konten yang paling banyak dikonsumsi oleh maryarakat, terutama pelajar (remaja) (Robin, 2006). Sehingga guru seudah seharusnya memiliki keterampilan dalam membuat konten audio dan video untuk bahan yang edukatif dan dapat digunakan banyak siswa.

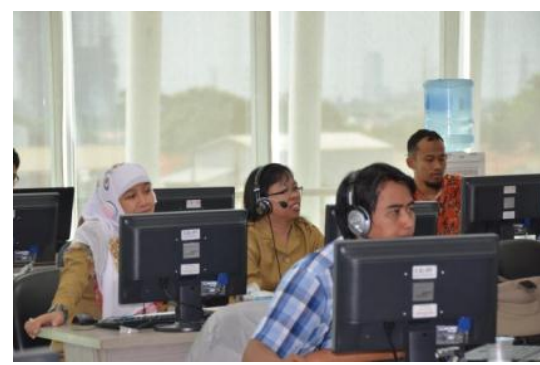

Gambar 8. Peserta mencoba menggunakan perangkat keras dan lunak pengolah audio dan video 


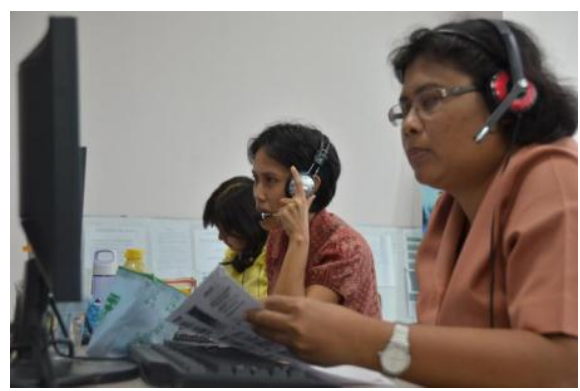

Gambar 8. Peserta mencoba menggunakan perangkat keras dan lunak pengolah audio dan video

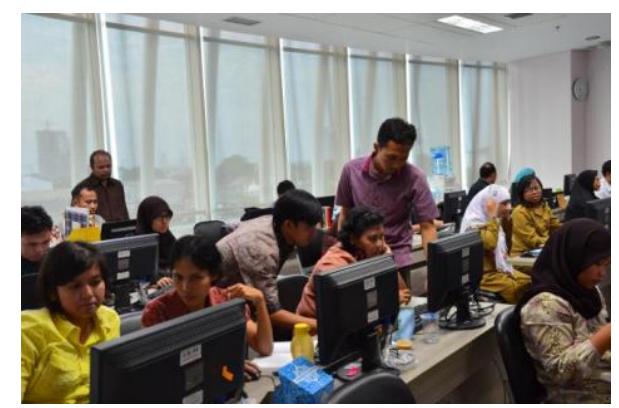

Gambar 9. Pendampingan instruktur dan asisten instruktur pada mata latih konten audio dan video

Pada hari kedua, mata pelatihan yang diberikan kepada peserta adalah electronic quiz, animasi pembelajaran, dan programming dasar. Pembuatan electronic quiz saat ini sangat penting dikuasai karena tes konvensional selama ini memiliki banyak kelemahan, dimulai dari pembuatan hingga pengolahan hasil tes. Melalui mata latih electronic quiz dengan aplikasi Wondershare Quiz Creator, para guru memiliki keterampilan dalam membuat soal dengan beragam tipe dan mendokumentasikan hasil tes dengan lebih rapih. Selain itu, e-quiz juga memberikan kemudahan untuk guru dalam mengirimkan tes kepada siswa secara cepat tanpa membutuhkan waktu untuk mencetak soal.
Mata
pembelajaran
diarahkan pembuatan simulasi sederhana untuk visualisasi sebuah prinsip. Pada kasus ini diberikan contoh pembuatan simulasi bergerak dari konsep gerak parabola, beserta contoh script yang digunakan. Ketika pelaksanaan mata latih ini, terlihat sekali keterampilan dasar yang dibutuhkan pada guru belum tampak. Sehingga pada mata latih ini, dibutuhkan banyak pendamping peserta untuk membantu menggunakan perangkat lunak pengolah animasi yang bernama Synfig Studio. Konten animasi ratarata paling banyak dibutuhkan oleh guru-guru pada bidang studi IPA dan Teknik, karena banyak prinsip abstrak yang harus disampaikan dalam bentuk konkrit yang terjadi dalam kehidupan sehari-hari. Oleh karena itu, konten animasi dianggap sangat sesuai untuk kebutuhan tersebut.

Materi terakhir dari kegiatan pelatihan ini adalah programming dasar dengan menggunakan perangkat lunak Processing. Tujuan awal dari mata latih ini adalah memperkenalkan konsep pemrograman kepada para peserta, dimana konten ini belum familiar dikalangan para guru, kecuali untuk guru bidang studi TIK atau di SMK teknik. Pada pelaksanaannya, ternyata animo guru untuk mempelajari mata latih ini terbilang cukup rendah karena pemahaman bahasa komputer yang tidak dimiliki. Oleh karena itu, pada mata latih ini, guru cukup mempraktekkan sedikit tutorial dan kasus untuk membuat project sederhana. 
Taufik Ikhsan Slamet', Agung Alfiansyah ${ }^{2}$, Wikky F. Al Maki ${ }^{3}$, Fathoni A. Musyafa ${ }^{4}$, Alfa Satyaputra ${ }^{5}$, Patmah Fathoni ${ }^{6}$, Shinta S. Andayani ${ }^{7}$, Sherly

Melinda $^{8}$, Dominggus Oktavianus ${ }^{9}$, Nuiza P. Yusuf ${ }^{10}$ / Aksiologiya: Jurnal Pengabdian Kepada Masyarakat. Vol.4, No.1, Februari 2020 Hal 118-130

\section{SIMPULAN}

Guru merupakan ujung tombak kurikulum, yang notabene paling memahami karakteristik para peserta didik, terutama tentang cara mereka belajar. Generasi milenial yang menjadi peserta didik saat ini sangat kecanduan dalam mengkonsumsi dan memproduksi informasi dalam jaringan terbesat dunia. Hal ini bisa menjadi keuntungan maupun ancaman bagi kualitas pembelajaran. Guru tentunya harus merespon ini dengan strategi yang sesuai dengan peserta didik saat ini, salah satunya adalah dengan menyediakan konten digital yang positif utamanya untuk keperluan pembelajaran.

Keterampilan dalam membuat atau memanfaatkan konten digital di internet adalah satu cara yang paling mudah dilakukan. Sehingga, guru harus cekatan dalam mencari sumber terbaru yang dapat dirujuk untuk mengembangkan ilmu untuk peserta didiknya. Selain itu, tidak hanya menggunakan dan menyampaikan konten kepada peserta didik, guru juga harus berupaya untuk mengajarkan originalitas karya (produk) yang digunakan. Oleh sebab itu, akan lebih baik jika guru tetap menggunakan material dan perangkat lunak yang berbasis open source. Sehingga tidak memunculkan pelanggaran dan tetap menghormati karya cipta orang lain.

Pelatihan pembuatakn konten digital berbasis open source dinilai peserta merupakan sebuah kemajuan. Bukan hanya dari segi keterampilan yang baru, namun mereka berpendapat bahwa siswa harus mulai mengenal etika teknologi yang salah satunya adalah mengikuti undangundang informasi dan transaksi elektronik. Dengan adanya pengenal terhadap material sumber terbuka (open sources) akan memotivasi siswa untuk melakukan kontribusi terhadap perkembangan teknologi.

\section{Ucapan Terimakasih}

Kegiatan ini dilaksanakan ketika penulis utama menjadi staf di Prodi Pendidikan Teknik Informatika dan Komputer di Surya College of Education. Terima kasih untuk segenap pihak yang membantu terselenggaranya kegiatan pengabdian pada masyarakat ini. Terima kasih secara khusus penulis sampaikan pada Ketua STKIP Surya, Agung Alfiansyah, Ph.D (Ketua Prodi Teknik Informatika dan Komputer tahun 2015), staf pengajar Prodi TIK (Dr.Eng. Wikky F. Al Maki, Fathoni A. Musyafa, M.Eng, Alfa Satyaputra, M.Sc, Patmah Fathoni, M.Eng, Shinta S. Andayani, S.Kom, Sherly Melinda, S.Pd, Dominggus Oktavianus, S.Pd., dan Nuiza P. Yusuf, S.Kom). Serta para mahasiswa Prodi PTIK STKIP Surya yang telah membantu keterlaksanaannya kegiatan.

\section{DAFTAR RUJUKAN}

Anderson, J., \& Glenn, A. (2003).

Building capacity of teachers/facilitators in technology-pedagogy integration for improved teaching and learning: Final report. Bangkok, Thailand: UNESCO, Asia and Pacific Regional Bureau for Education

Bandura, A., \& Walters, R. H. (1963). Social learning and personality development.

Bichelmeyer, B. (2005). The ADDIE model: A metaphor for the lack 
Taufik Ikhsan Slamet ${ }^{1}$, Agung Alfiansyah ${ }^{2}$, Wikky F. Al Maki ${ }^{3}$, Fathoni A. Musyafa ${ }^{4}$, Alfa Satyaputra ${ }^{5}$, Patmah Fathoni ${ }^{6}$, Shinta S. Andayani ${ }^{7}$, Sherly

Melinda ${ }^{8}$, Dominggus Oktavianus ${ }^{9}$, Nuiza P. Yusuf ${ }^{10}$ / Aksiologiya: Jurnal Pengabdian Kepada Masyarakat. Vol.4, No.1, Februari 2020 Hal 118-130

of clarity in the field of IDT.

IDT Record.

Davis, A. L. (2013). Using instructional design principles to develop effective information literacy instruction: The ADDIE model. College \& Research Libraries News, 74(4), 205207.

De Ree, J., Muralidharan, K., Pradhan, M., \& Rogers, H. (2015). Double for nothing? Experimental evidence on the impact of an unconditional teacher salary increase on student performance in Indonesia. National Bureau of Economic Research.

Fullan, M. (1994). Coordinating topdown and bottom-up strategies for educational reform.

Systemic Reform: Perspectives on Personalizing Education, 724.

Gustafson, K. L., \& Branch, R. M. (2002). What is instructional design. Trends and Issues in Instructional Design and Technology, 16-25.

Molenda, M. (2003). In search of the elusive ADDIE model. Performance Improvement, 42(5), 34-37.

OECD. (2015). PISA 2015 Results. Retrieved from http://www.oecd.org/pisa/keyfi ndings/

Preparing Students To Produce

Digital Content. (2015,

October 14). Retrieved
December 15, 2019, from ELearning Industry website: https://elearningindustry.com/p reparing-students-to-producedigital-content

Robin, B. (2006). The educational uses of digital storytelling. Society for Information Technology \& Teacher Education International Conference, 709-716.

Association for the Advancement of Computing in Education (AACE).

Tatang, M. A. (2007). Institutional Needs and Assessment of S1 Elementary School Education Program Develeopment Implementation and Use of ICT at UNY. International Workshop Strengthening Institutional Capacity in Elementary Teacher Education, July 30th-August 2nd, USINTEC-Universitas Negeri Jakarta.

Yi, M. Y., \& Davis, F. D. (2003). Developing and validating an observational learning model of computer software training and skill acquisition.

Information Systems Research, 14(2), 146-169.

Yusuf, A. E. (2016). The implementation of ICT based education in elementary teacher education (PGSD) in Indonesia. Humaniora, 7(1), 814. 